Stawomir Juszczyk

Warsaw University of Life Sciences

\title{
LISTING OF SHARES OF SOME COMMERCIAL BANKS AND FINANCIAL SERVICES COMPANIES IN POLAND
}

\begin{abstract}
The purpose of the research was to identify the volatilities of daily quotes of banks and financial services companies listed on Warsaw Stock Exchange in the six-year period ie 20112016. It was found that the volatility of the stock price of the eCard was the strongest correlated with BPH stock price volatility, while the volatility of KREDYTIN stock prices was strongly correlated with the volatility of $B Z W B K$ shares, ING and PKO BP. The strongest correlation between the stock prices of banks and the surveyed financial services companies was on the day of their listing. Unlike banks, financial services companies are highly diversified.
\end{abstract}

Key words: share price, correlation, econometric modeling

\section{Introduction}

Recognition of factors influencing the formation of stock quotes is an important objective not only for investors, but also for quoted entities. In practice, changes can be made to individual companies and entire industries or groups. They react to the same factor, but they can also go in the opposite direction. However, homogeneous groups of companies may react to external variations in a given period not always immediately and in the same way. Therefore, the area of this issue may also be interesting. Bank quotes are often a benchmark for other quotes, including those of financial services companies. However, there are no regularities in this regard. Therefore, studying these relationships are complex, interesting and potentially useful.

The purpose of the study was to identify the volatilities of daily quotes of banks and companies in the financial services sector listed on the Warsaw Stock Exchange in the six-year period, ie 2011-2016. The indirect objective was to determine the similarities and differences between stock prices of selected entities. In the research process, the following hypothesis is established: the correlation between changes in share prices of banks and companies in the financial services sector is at least significant.

In order to verify the hypothesis and to achieve the objective, the values of daily stock quotes of banks and financial companies quoted on the Warsaw Stock Exchange in 2011-2016 were used. The main criterion for selecting companies was the length of their listing on the stock exchange, so that each of them was quoted uninterruptedly from the beginning of 2011 to the end of 2016, the only exception was ECARD, whose listing was terminated in February 2016. The banks and financial companies included in the study are:

1. PKO BP - Powszechna Kasa Oszczędności Bank Polski- Polish universal bank founded in 1929 as a state commercial bank, since 1998 a joint stock company listed on the WSE, 
2. BANK ZACHODNI WBK S.A. - a universal bank with registered office in Wrocław. One of the largest banks in Poland in terms of asset value and in terms of number of outlets, listed on the stock exchange since 2001,

3. ING - Bank Śląski S.A. - universal bank, has been operating since 1989. On the stock exchange listed since 1994,

4. BPH - Bank BPH - present on the Polish market for more than 20 years. Its shares were listed on the Warsaw Stock Exchange until December 14, 2016.

5. RUBICON PARTNERS S.A. - an investment banking services company listed on the stock exchange since 1997. The peak moment for company listing is 2005 ,

6. ECARD S.A. - a company was established in Gdańsk on March 20, 2000. Cooperates with banks such as BZ WBK, PKO BP and others. It covers over $70 \%$ of online payment cards. Debut on the stock market in 2006, closing in February 2016,

7. KREDYT INKASO S.A. - a company based in Warsaw, dealing with collection of receivables. It has been operating since 2001, while on the stock market has been listed since 2007,

8. PRAGMA FAKTORING S.A. - the company has been operating on the market since 1996, but as a joint stock company only since 2007. In the same year for the first time listed on the Warsaw Stock Exchange. The Company deals with receivables and loans. It is part of the Pragma Inkaso Group.

WSE publications, financial statements of banks and audited financial companies were used. According to the Starzyńska division [2009, p. 41], it is assumed that the strength of the correlation between the two features is:

- unclear when $|\operatorname{rxy}| \leq 0,2$

- distinct but low when $0.2<\mid$ rxy $\mid \leq 0.4$

- moderate when $0.4<|\operatorname{rxy}| \leq 0.7$

- significant when $0.7<\mid$ rxy $\mid \leq 0.9$

- very strong when rxy>0.9.

The above division was used to evaluate the strength of correlations between the tested variables. In the course of the research, traditional statistical methods for econometric modeling were used as well.

Bearing in mind the volatility of stock prices on the stock market, it is worth emphasizing that the appearance of unpredictable information results generally stronger investor reactions than in the case of expected information. So, whether the information will influence the quotes is determined, among other things, by the degree of investor surprise [Sławiński 2006, p. Łon 2006, p. 21-29]. The key is that the changing economic climate, investors assess according to indicators, which are usually divided into three groups [Yamarone 2006, p. 21; Reilly F.K., Brown K. K. 2001, p. 622-623]:

- ahead (forecasting) - reflecting investor expectations, such as new order information;

- current (convergent) - reflecting the current state of the economy (data on the pace of

production, growth of national income, employment); 

downturn has

- delayed (responding to a delay) - confirming or not confirming that a already occurred, preceded by pre-emptive indicators (for example data on the development of investments and wages).

There are many factors that determine changes in stock prices, they are outside of GDP, budget deficit, current account deficit, inflation, unemployment and interest rates, taxes and others [Tarczyński, Mojsewicz 2008, pp. 61-63]. The rise in unemployment is often a reason for stock selling, while the decline in unemployment generally encourages investors to buy securities [Yamarone 2006, pp. 86-87]. In the situation of a higher budget deficit than the 3\% of GDP allowed by the European Economic and Monetary Union, there is usually a slow outflow of investors from a given country, which generally leads to a weakening of the national currency. Similarly, in the situation of public debt, which is $60 \%$ of GDP acceptable by the European Economic and Monetary Union [Jajuga $2007 \mathrm{a}, \mathrm{p}$. 125]. The empirical findings on the impact of GDP on the volatility of stock quotes, most point to a positive correlation between them. This is not a constant rule. In many cases, the researchers also say that investors are also influencing future economic conditions and thus indirectly affecting the rate of GDP growth.

High inflation also generally has a negative impact on share prices. It is assumed that the relationship between stock prices and small inflation should have a positive sign.

Shears should, however, play a protective role. However, some of the results of the study lead to different conclusions, indicating in this regard the correlation with the negative sign. According to Sharpe, an increase in inflation may lead to a decline in stock prices as it is accompanied by an increase in expected returns but also higher expected rates of return. Another factor influencing stock price changes is interest rates. As their level grows, stock prices are usually falling and vice versa, so a decrease in interest rates is most likely to increase stock prices. It is known that stocks and bonds can be competitive in terms of investment opportunities. Therefore, a reduction in interest rates may affect the price of bonds and the shares may be overestimated [Jajuga 2007 b, p. 120].

Shaping volatility of stock prices is also linked to the situation on international exchanges. The world economy is a multidimensional system of connected vessels, which enables rapid spread of positive trends as well as financial crises [Ostaszewski 2013, p. 78]. Prokopowicz defines the stock market as a component of a syndicate of vessels, where vessels are highly interconnected financial markets [2010, p. 308]. One example is the financial crisis, launched in 2008 on the US subprime mortgage market. According to Kozak [2013, p.101] the global financial crisis has indirectly affected the pace of economic growth in Poland and also increased risk aversion among investors. The consequences of this crisis were also felt by countries unrelated to its source, including Poland. European markets, especially in the euro zone, are strongly correlated, so that one of them affects the other.

In literature, the topic of linking return rates of various stock indices is often discussed. However, correlation coefficients are unstable over time. This makes it difficult to manage of the investment portfolio. It is also difficult to estimate the return on shares. The asymmetry of information also has an impact on the correlation between volatility on financial markets. Volatility usually increases as uncertainty about future 
market conditions and country policy increases. Polish investors often rely on publications from the United States economy. If the situation on the financial markets is calm, data from the Polish market are more important and vice versa. However, changes on the US stock exchange have a strong impact on stock price movements on the WSE.

Aranowski and Hozer [2002, pp. 170-174] have shown a strong and positive correlation between the values of the Polish WIG20 index and the Dow Jones Industrial Average, one of the most important stock indices listed on the New York Stock Exchange and the NASDAQ (National Association of Securities Dealers Automated Quotations). A strong correlation between the indices on the US and Polish stock exchanges was revealed by Przekota. High correlation showed that the investors of the WSE in 2006-2008 reacted quickly to the changes of the Dow Jones index.

\section{Findings}

In the years 2011-2016, listed banks did not undergo significant organizational and legal changes. The exception was BZ WBK, which merged with the smaller Kredyt Bank. This event had an impact on BZ WBK's financial results, but it did not significantly affect its stock ratings [Sobolewska 2016 p. 45]. BPH and PKO BP's share prices did not exceed 50 Polish New Zloty (PNZ), and ING recorded a slight increase, remaining in this trend until the end of the research period. More detailed econometric analysis is presented in table 1 .

Table 1. Econometric results of banks quotations for the years 2011-2016

\begin{tabular}{|l|r|r|r|r|}
\hline \multirow{2}{*}{\multicolumn{1}{c|}{ Items }} & \multicolumn{4}{c|}{ Banks } \\
\cline { 2 - 5 } & \multicolumn{1}{c|}{ BPH } & \multicolumn{1}{c|}{ PKO BP } & \multicolumn{1}{c|}{ ING } & BZ WBK \\
\hline Average & 49,93816 & 37,33637 & 95,79949 & 278,7869 \\
\hline Standard error & 0,351657 & 0,126244 & 0,642876 & 2,165728 \\
\hline Standard deviation & 10,73018 & 3,786782 & 19,47577 & 65,63375 \\
\hline Sample variation & 112,0008 & 14,42555 & 379,6962 & 4306,486 \\
\hline Minimum & 29,82 & 29,32 & 66,6 & 210 \\
\hline Maximum & 86 & 47,3 & 143,9 & 434 \\
\hline
\end{tabular}

Source: Own calculations.

The stock price quotations for 2011-1016 are shown in Figure 1. 


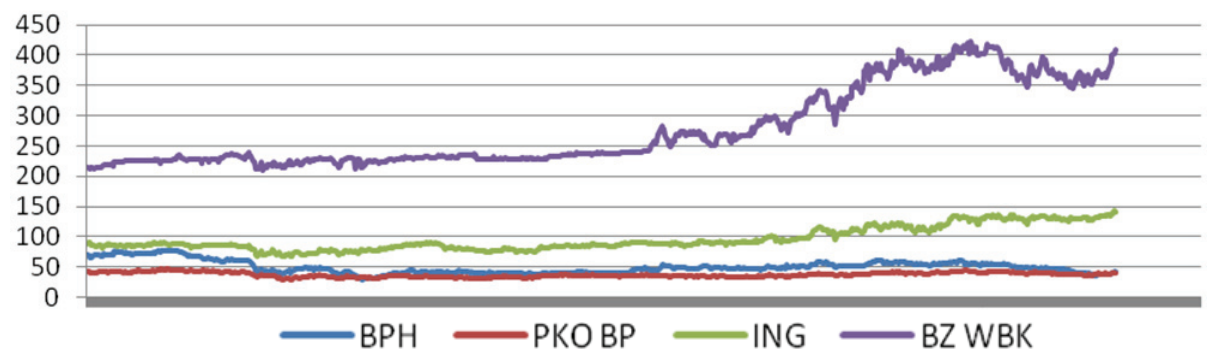

Figure 1. Daily quotes of shares of the surveyed banks in 2011-2016 Source: Own study based on WSE data

The stock prices of the surveyed banks were generally upward trend, but the financial results of individual banks were not the most important factor in the changes in stock price quotes. Companies surveyed in the financial services sector in 2011-2014 did not undergo significant administrative and legal changes affecting their share prices. The eCard and Rubicon shares did not trade 1 PNZ / share, whereas KredytIn and Pragma Factoring shares were respectively PNZ 15.24 and PNZ 16.68 respectively. A more detailed statistical analysis are presented in table 2.

Table 2. Econometric results of listed companies for the years 2011-2016

\begin{tabular}{|c|c|c|c|c|}
\hline \multirow{2}{*}{ Items } & \multicolumn{4}{|c|}{ Companies from the financial services sector } \\
\hline & eCARD & KREDYTIN & PRAGMA FA & RUBICON \\
\hline Average & 0,292708 & 15,2469 & 16,67634 & 0,729414 \\
\hline Standard error & 0,002333 & 0,117563 & 0,052463 & 0,026647 \\
\hline Standard deviation & 0,074865 & 3,560896 & 1,587381 & 0,807526 \\
\hline Sample variation & 0,005703 & 12,67981 & 2,51971 & 0,653065 \\
\hline Minimum & 0,16 & 9,57 & 12,47 & 0,07 \\
\hline Maximum & 0,48 & 25,66 & 24 & 3,72 \\
\hline
\end{tabular}

Source: Own calculations.

Listing of shares of KredytIn S.A. and PragmaFa S.A. In particular, the fluctuations and average values were around 10-25 PNZ per share. Rubicon and eCard stock were characterized by low levels. The only significant increase was in 2014 on Rubicon's stock, due to changes in management. Stock quotes are shown in Figure 2. 


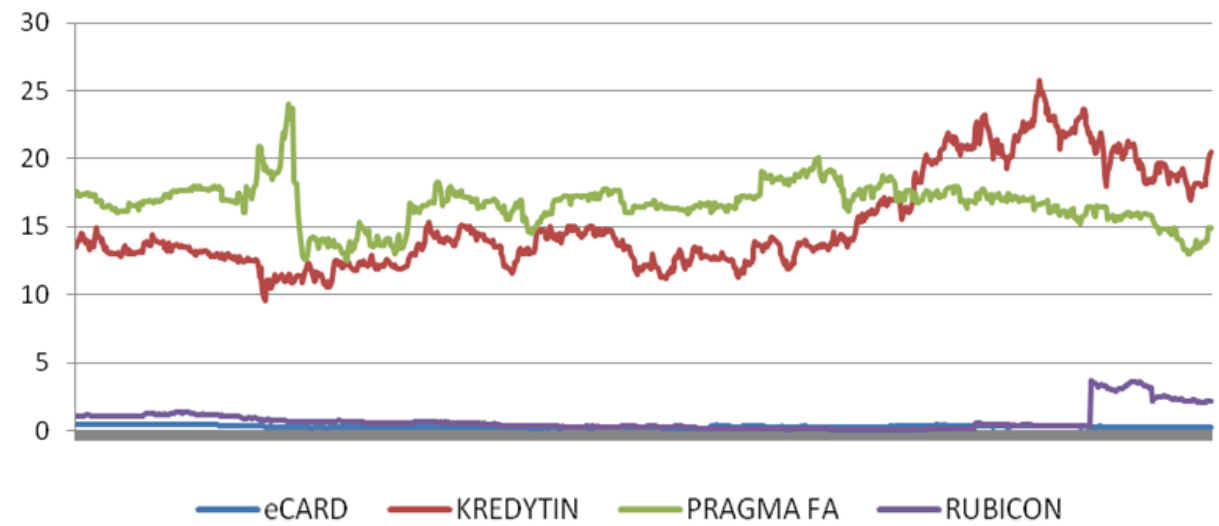

Figure 2. Daily quotations of shares of the audited financial companies in 2011-2016 Source: Own study based on WSE data

It can be assumed that share prices of banks and companies in the financial services sector depend on many factors both external and internal. Starting from 2011, the situation on the markets has stabilized, resulting in better investor sentiment. Equally important for stock quotes of companies in the financial services industry, their financial results were more important than overall market situation. Table 3 presents the strength of correlation between the surveyed entities.

Table 3. Correlation between share prices of banks and financial services companies in the years 2011-2016

\begin{tabular}{|l|r|r|r|r|r|r|r|r|}
\hline Entities & BPH & $\begin{array}{c}\text { PKO } \\
\text { BP }\end{array}$ & ING & $\begin{array}{c}\text { BZ } \\
\text { WBK }\end{array}$ & eCARD & KREDYTIN & $\begin{array}{r}\text { PRAGMA } \\
\text { FA }\end{array}$ & RUBICON \\
\hline BPH & 1,00 & $\mathbf{0 , 8 2}$ & 0,16 & 0,12 & $\mathbf{0 , 8 8}$ & 0,19 & 0,27 & 0,12 \\
\hline PKO BP & $\mathbf{0 , 8 2}$ & 1,00 & 0,51 & 0,42 & 0,72 & 0,49 & 0,12 & 0,38 \\
\hline ING & 0,16 & 0,51 & 1,00 & $\mathbf{0 , 9 5}$ & 0,11 & 0,90 & $-0,12$ & 0,45 \\
\hline BZ WBK & 0,12 & 0,42 & $\mathbf{0 , 9 5}$ & 1,00 & 0,07 & $\mathbf{0 , 9 3}$ & $-0,07$ & 0,26 \\
\hline
\end{tabular}

Source: Own research.

Taking into account the results of the studies presented in table 3., the hypothesis that the correlation between changes in share prices of the surveyed banks and companies in the financial services sector is at least significant - only partially confirmed.

So BPH quotes were used to study the volatility of stock quotes of eCard in the years 2011-2016. Final results for the analysis conducted with BPH quotations are presented in table 4 . 
Table 4. Regression model of eCard listing for 2011-2016

\begin{tabular}{|l|r|r|}
\hline Parameter & Coefficients & Student's t-test values \\
\hline Constant value & $-0,0186$ & $-3,3219$ \\
\hline BPH & 0,0062 & 56,8259 \\
\hline
\end{tabular}

T critical value $=1,9625$ dla $\alpha=0,05$

Source: Own research.

In the first stage of modeling, the value of t-statistics for PKO BP was lower than the critical value. In the second stage on the basis of the determined values a model with a determination coefficient of 0.7744 was constructed, indicating that in the years 20112016 , the volatility of stock prices of eCard resulted from the volatility of share prices quoted by BPH. The econometric model describing the price level of eCard shares could be written for the analyzing period was as follows:

\section{eCard share price $=\mathbf{- 0 . 0 1 8 6}+\mathbf{0 . 0 0 6 2} \times \mathrm{BPH}$ share price}

The impact of BPH's listing on eCard S.A. in the years 2011-2016 was positive as indicated by the plus sign of the regression coefficient. Thus, the increase in the price of $\mathrm{BPH}$ shares, for example by $10 \mathrm{PNZ}$, was associated with the average increase in the price of eCard shares by 6.2 pennies.

In view of the correlation coefficient for econometric modeling, it was possible to use the valuation of KredytIn shares, taking into account stock quotes of three banks, namely BZ WBK, ING and PKO BP. Regression analysis was performed, and results are presented in table 5 .

Table 5. KREDYTIN regression model for the years 2011-2016

\begin{tabular}{l} 
Table 5. KREDYTIN regression model for the years 2011-2016 \\
\hline \multicolumn{1}{|c|}{ Parameter } \\
Constant value
\end{tabular}

T critical value $=1.9625$ for $\alpha=0.05$

Source: Own study.

Based on the analysis data, a model describing the price level of KredytIn shares was established, as follows:

KREDYTIN share price $=-\mathbf{2 , 5 1 4 8 8 8 1 6 8}+\mathbf{0 , 1 1 1 4 0 2 8 6 3} \times$ PKO BP share price $+\mathbf{0 . 0 1 2 7 0 9 3 1 3} \times$ ING share price $+\mathbf{0 . 0 4 4 6 0 0 8 1 4} \times$ BZ WBK share price

The increase in stock price quotations of PKO BP, ING and BZ WBK banks had a positive impact on stock prices of KredytIn S.A. Thus, for example, increases in stock quotes of these banks, for example by $10 \mathrm{PNZ}$, were accompanied by increases in 
KredytIn quotations respectively by: over $1.11 \mathrm{PNZ}$; nearly $0.13 \mathrm{PNZ}$ and almost 0.45 PNZ.

\section{Conclusions}

The research is fragmentary. They were based on the daily quotes of shares of selected banks and financial services companies listed on the Warsaw Stock Exchange. The results can not therefore be generalized to all banks and financial companies in the financial services sector. They may have only an auxiliary character. Based on the research, the following conclusions were made:

1. The volatility of stock prices of eCard shares was most strongly correlated with the volatility of BPH and PKO BP shares, while the volatility of KREDYTIN stock prices was most strongly correlated with the volatility of BZ WBK, ING and PKO BP shares.

2. The strongest correlation between share price quotations of banks and the surveyed financial services companies was on the day of their quotation. Thus, changes in stock price quotes of companies with respect to stock quotes of banks were followed with a slight delay, usually less than one day. It is possible that the time span of subsequent listing changes was several hours, but this would require further detailed research in this regard.

3. The surveyed banks showed a stronger correlation among themselves than with financial services companies, especially PRAGMA FAKTORING and RUBICON. This could have been due to the different specializations of those companies concerned. Financial services companies are strongly diversified as to the scope of their business and their relationship with the results of commercial banks.

\section{Bibliography}

Aranowski A, Hozer M., Polski rynek kapitałowy na tle rynków zagranicznych. Rynek kapitałowy. Skuteczne inwestowanie, Uniwersytet Szczeciński, Szczecin 2002.

Jajuga K., Elementy nauki o finansach, Wydawnictwo PWN, Warszawa 2007 a.

Jajuga K., Podstawy inwestowania na rynku papierów wartościowych, Wyd. GPW, Warszawa $2007 \mathrm{~b}$.

Kozak S., Konkurencja w sektorze bankowym i sektorze ubezpieczeń oraz jej uwarunkowania $i$ pomiar, Wydawnictwo SGGW, Warszawa 2013.

Łon E., Rynek akcji - barometr sytuacji makroekonomicznej. Ekonomika i Organizacja Przedsiębiorstwa, $\mathrm{nr}$ 5, 2006.

Ostaszewski J., Finanse, Difin, Warszawa 2013.

Prokopowicz D., Rynki Finansowe, Difin, Warszawa 2010.

Pytkowski W., Organizacja badań i ocena prac naukowych, PWN, Warszawa 1981.

Reilly F.K., Brown K.C., Analiza inwestycji i zarzqdzanie portfelem, PWE, Warszawa 2001.

Sławiński A., Rynki finansowe, PWE, Warszawa 2006.

Sobolewska U., Zmienność notowań akcji banków i spótek z sektora ustug finansowych... ,

Warszawa 2016.

Starzyńska W., Podstawy statystyki, Difin, Warszawa 2009. 
Tarczyński W., Mojsewicz M., Zarzadzanie ryzykiem. Podstawowe zagadnienia, PWE, Warszawa 2008.

Yamarone R., Wskaźniki ekonomiczne. Przewodnik inwestora. Helion, Gliwice 2006.

\section{Other sources:}

Stock Exchange, Official Publication of the Warsaw Stock Exchange.

Financial statements of BZ WBK SA

Financial statements of PKO BP SA

Financial statements of ING Bank Śląski S.A.

Financial statements of BPH S.A.

Financial statements of Rubicon Partners S.A.

Financial statements of eCard S.A.

Financial statements of KredytIn S.A.

Financial statements of Pragma Factoring S.A.

www.gpw.pl

www.bzwbk.pl

www.pkobp.pl

www.ingbank.pl

www.bph.pl

www.rubiconpartners.pl

www.ecard.pl

www.kredytinkaso.pl

www.pragmafaktoring.pl

\section{Streszczenie}

Celem badań było rozpoznanie zmienności dziennych notowań cen akcji banków oraz spółek z sektora usług finansowych notowanych na GPW w Warszawie w sześcioletnim okresie badawczym tj. w latach 2011-2016. Ustalono m.in., że zmienność notowań cen akcji spółki eCard najsilniej była skorelowana ze zmiennością cen akcji BPH, zmienność zaś cen akcji KREDYTIN najsilniej była skorelowana ze zmiennością cenami akcji BZ WBK, ING i PKO BP. Najsilniejsza związek między notowaniami cen akcji banków i badanych spółek usług finansowych występowała w dniu ich notowania. W przeciwieństwie do banków, przedsiębiorstwa sektora usług finansowych są silnie zróżnicowane.

Słowa kluczowe: ceny akcji, związek korelacyjny, modelowanie ekonometryczne

Informacje o autorze:

Prof. dr hab. Slawomir Juszczyk

Warsaw University of Life Sciences

Faculty of Economic Sciences,

Department of Finance

e-mail: slawomir_juszczyk@sggw.pl 